\title{
Dental students' dropout rates and professional practice adherence among graduates from a public institution
}

\author{
Freddy Okino*; Alexandre Rodrigues Filho*; Victor Fernando Jacomini*; Alessandro De Carli**; \\ Albert Schiaveto de Souza***; Jussara Peixoto Ennes*** \\ * Undergraduate dental student, School of Dentistry, Federal \\ University of South Mato Grosso \\ ** Full Professor, Dental School, Federal University of South \\ Mato Grosso \\ *** Full Professor, Bioscience Institute, Federal University of \\ South Mato Grosso
}

Received: 06/05/2020. Approved: 02/25/2020.

\begin{abstract}
This study presents a quantitative analysis of data related to the dropout rates at the School of Dentistry at Federal University of South Mato Grosso (FAODO-UFMS) and graduates' professional activity, covering the period between its implementation in 1964 until the year 2015. The data obtained were associated with the existing admission system during the period. The graduates' adherence to the professional practice was investigated and the professional practice time of these graduates and of those ones from other Higher Education Institutions (HEI) in the state of South Mato Grosso (MS). A significance level of 5\% was adopted. The Unified Selection System (USS) has a strong correlation with Dental School dropout rates at UFMS. There was no statistical difference in the comparison between students who were admitted by nationwide competition (Vestibular), quotas, or through the use of vacant positions. The average time extent of Dentistry's practice has decreased in MS in recent decades, being statistically lower for the UFMS' graduates than for those ones from other HEI ( $\mathrm{p}<0.001)$. Of the graduates from the years 1971 to 1990, the percentage of those who have been/are in practice for over 30 years reached $71.43 \%$. The dropout rates at FAODO-UFMS increased with the use of USS as an admission system. Both USS and increase in vacancy at FAODO-UFMS did not show favorable results when related to adherence to the course. The average time of practice for Dentistry in MS has been decreasing, especially for those not graduated from FAODO-UFMS. Descriptors: Dropout. Education, Higher. Professional Practice.
\end{abstract}




\section{INTRODUCTION}

Dropout rates in higher education have been increasing ${ }^{1,2}$ and this is a matter of worldwide concern ${ }^{3-7}$. The rates vary considering school option, institution, region and country $^{3,5,6}$. In Brazil, data from the Ministry of Education (ME) show this increase: $11.4 \%$ of students dropped out of the higher education institution where they were admitted, in $2010^{7}$; and in 2014 it reached a level of $49 \%^{8}$. In 2018, of the approximately two million and six hundred thousand students enrolled in public universities, around 204.000 had gone on a leave of absence (7.04\%) and 324 thousand had asked to be released from the course $(12.4 \%)$. In private institutions, these numbers were more significant, with approximately nine million, four hundred thousand students, of which around one million requested a leave of absence $(11.7 \%)$ and one million eight hundred thousand students had withdrawn from the course $(20.76 \%)^{9}$.

The studies point to a multifactorial motivation for high dropout rates at HEI, involving the student and/or the educational institution $^{8,10-12}$. The association of the selective process for admission and the dropout rate has drawn some attention ${ }^{13}$. Higher education's selection model varies within the same country or among countries ${ }^{3,5,11,14}$ : many are unified, ${ }^{16-19}$ although with different levels of difficulty.

In Brazil, the almost exclusive modality used for admission into Higher Education Institutions (HEI) was the Vestibular exam, until the decade of 2010, when new modalities were introduced. The National High School Exam (NHSE), established in $1998^{20}$, initially proposed to identify students' performance in specific areas of knowledge, started having other applications, such as being used as a criterion for admission at HEI. The Unified Selection System (USS), implemented by the ME in $2010^{21}$, allowed the candidate who took the NHSE to apply to different universities that adopt it and choose different courses based on the possibilities available with their scores. In the early 2000s the Law of Directives and Bases to Education (LDB) was approved. It proposes that vacancies determined by student evasion be filled by academics from other institutions by selection process, which has been implemented at UFMS since 2008. Law N. 12711 of August 29, $2012^{23}$ established that federal universities should allocate quotas of up to $50 \%$ of their student body to students from the public network education system, thus constituting a reserve for this group of students and, later, to low-income candidates, blacks, browns and native Brazilians. At FAODO-UFMS in 2013, $12.5 \%$ of the vacancies were offered to the quota system; $25 \%$ in 2014 ; $37.5 \%$ in 2015; and finally, 50\% from 2016 onwards.

In the past, with Vestibular as the admission process, the main factors related to dropout rates were approval in another HEI and/or school and failure ${ }^{24}$. It is necessary to investigate the extent to which these new admission modalities reflect on higher education adherence, as being far from one's family and the financial and emotional impact of this distance have already been associated with dropout ${ }^{3,6,25}$.

The knowledge about the indexes and factors that determine the dropout rates in higher education may help in the search for alternatives to predict and prevent it since it is an issue that has an impact on the individual, overwhelmed by feelings of frustration; on their families, which have expectations and provide financial support ${ }^{6}$; on the labor market, which has become overloaded with investment on human resources' qualification $^{3,4}$ and on society, penalized by the reduction in qualified human resources ${ }^{6}$. These issues reflect and interfere with economic growth $^{6}$.

Dental practice requires skills that some 
candidates do not consider by the time they apply for higher education, and that may contribute to one's inability to perform, such as manual motor skills ${ }^{26}$. There is also the implicit high financial cost, which is a reality regardless of the educational system, public or private, and the unrealistic expectations regarding professional remuneration. These issues may contribute to dropout rates or professional dissatisfaction, resulting in unmotivated and/or insufficient practice $^{27}$ and, finally, leading to the abandonment of the practice ${ }^{26}$.

This study aimed to identify the dropout rates at FAODO-UFMS from 1964 to 2015 and to verify the professional activity of graduates from FAODO-UFMS from 1971 to 2015.

\section{MATERIAL AND METHODS}

This is a quantitative, analytical, timeseries study carried out in the city of Campo Grande, from 2018 to 2020.

The data related to students' admission and graduation from FAODO-UFMS since it started in 1964 up to 2005, were obtained from the academic secretariat of the FAODO-UFMS. The data related to the years after 2005 were provided by the Academic Issues Office (AIO).

The percentage of graduates per class was identified by the list of admitted students who graduated, even if the time required to finish the program was longer than the pre-established one. Dropout was identified as the failure to graduate. Compulsorily transferred students were excluded, either due to dismissal or nonattendance, after the first enrollment. The applicants were divided into groups, considering the admission process: Vestibular, USS, Quotas, and Use of Vacancies.

An analysis was carried out to identify the rate of adherence of the FAODO-UFMS' graduates to the professional practice from 1971 to 2015 . The list of graduates was compared with data from the Dentistry Regional Council of MS (DRC-MS) in to identify the activity or dismissal, and with data obtained from the Federal Council of Dentistry (FCD) to locate those who were registered in other states. An investigation was carried out in search engines to identify cases of registration not found in the different Regional Councils or in the Federal Council. The data from the graduates from other HEIs, which were registered in the DRC-MS were also analyzed. A correlation between professional practice time of UFMS' graduates with those of other HEIs' was carried out. An analysis of professional practice time of UFMS' graduates was performed in decades, between 1971 and 2018 to investigate for how long those who were graduated in a determined period have worked (up to 9 years; up to 20 years; up to 29 years and more than 30 years) was done.

The Student's $t$-test was used to compare different admission processes concerning the average dropout rates; and between the FAODOUFMS versus other institutions, regarding the years of practice. The comparative analysis of the percentage of undergraduate students admitted through Vestibular, quota holders, and those who filled the vacant positions was performed through one-way ANOVA test. The identification of the adherence rate of Dentistry graduates from FAODO-UFMS to the professional practice in MS or in other states was carried through one-way ANOVA test, followed by Tukey's post-test, as well as the comparison between the length of professional practice time of the graduates from the different HEI in decades and the identification of the average length of professional practice time among those who stopped working in the area. The chi-square test performed the verification of the association between the decade when graduated students from FAODO-UFMS and the range of practice time. The statistical analysis was performed using the statistical program 
SigmaPlot, version 12.5 , considering a significance level of $5 \%$.

This study was approved by the Research Ethics Committee of UFMS, CAAE, Report N. 2.598.529.

\section{RESULTS}

In the FAODO-UFMS, the number of annual vacancies was 32 since 1964, with an expansion to 40 seats per year in 1999 and to 50 in 2011. For those admitted through Vestibular, between 1964 and 2010, the average relative dropout was significantly lower than between 2011-2015, when the admission was through USS (figure 1).

Figure 2 shows the percentages of students selected by Vestibular (74.123 \pm 5.698$)$, by Quotas (60.798 \pm 5.564$)$ and by filling vacant positions $(60.931 \pm 9.076)$ who graduated, and no significant difference was found when comparing them (one-way ANOVA test, $\mathrm{p}=$ $0.353)$.

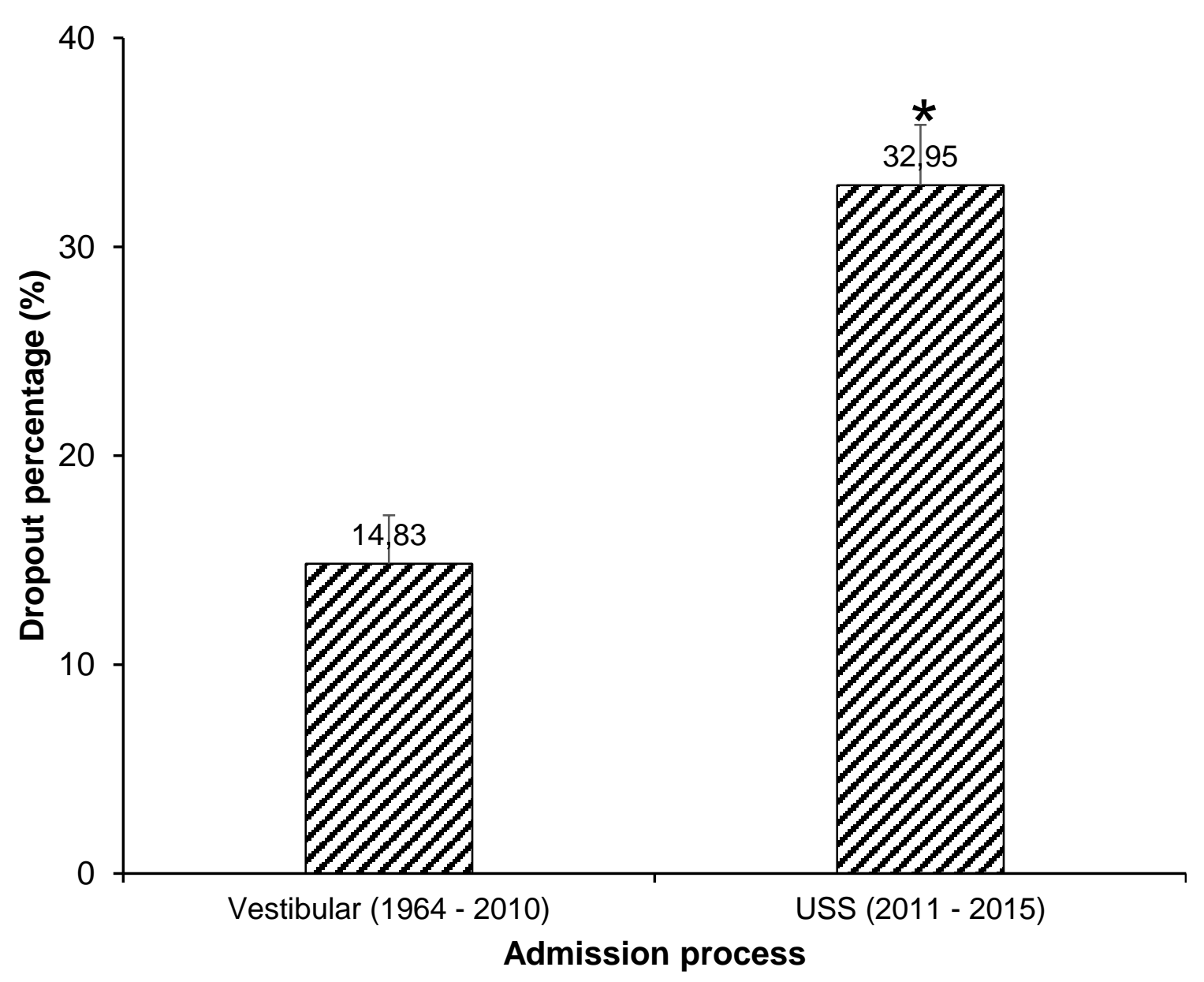

Figure 1. Average student dropout percentage at the FAODO-UFMS, according to the admission process. * Significant difference in relation to the Vestibular as an admission process (Student's $t$ test, $\mathrm{p}<0.001)$ 


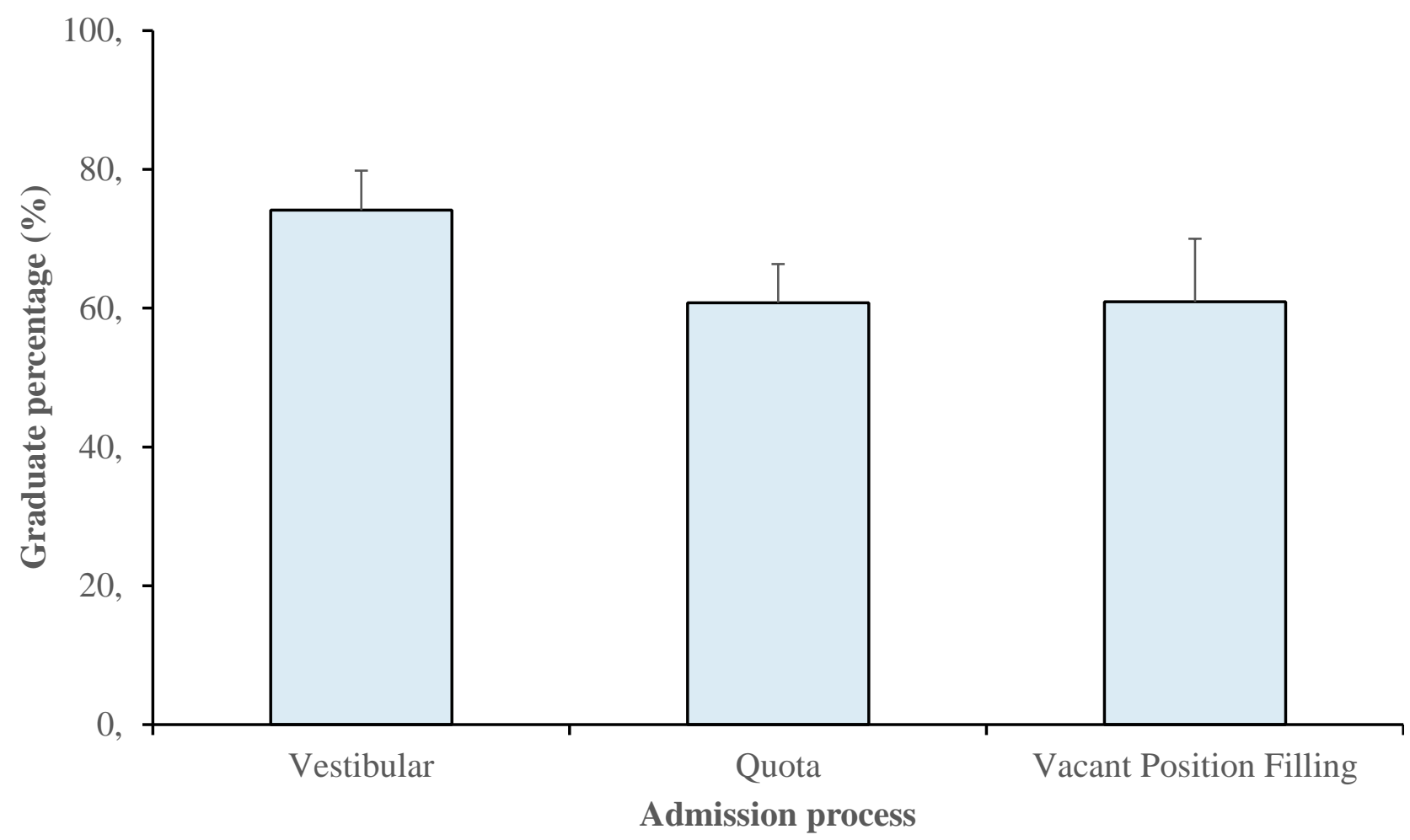

Figure 2. Percentage of students who graduated at FAODO-UFMS, according to the admission process (One-way ANOVA test, $\mathrm{p}=0.363$ )

FAODO-UFMS graduates' adherence to professional practice has shown to be high (93\%), since they started entering the labor market, showing a growing percentage of up to $100 \%$, in 1998, when a decline was identified between 1998 and 2008; afterward, the percentage started increasing once more (figure 3 ).

The average time of practice among FAODO-UFMS graduates was longer than that of graduates from other HEI in all analyzed periods (figure 4), and the difference was always significant (Student's $t$-test, $\mathrm{p}<0.001$ ).

Figure 5 shows the percentage of professionals who worked for at least 29 years in the decades between 1971-1980 and 1981-1990.

As to the relation between graduation date of UFMS' graduates and time of practice in decades, from the 127 graduates between 1971 and $1980,3.94 \%$ of them remained in practice for one decade; $8.66 \%$ for one-two decades; $17.32 \%$ for two-three decades and $70.08 \%$ for more than three decades. Between 1981 and 1990, from the 259 graduates $5.40 \%$ remained in practice for one decade, $4.63 \%$ for one-two decades, $18.54 \%$ for two-three decades and $71.43 \%$ for more than three decades. Between 1991 and 2000 from the 239 graduates $6.22 \%$ remained in practice for one decade and $9.20 \%$ for one-two decades. There was no significant association between the maximum time of practice in decades and the period of graduation, from 1971 to 2000. (Considering three ranges only: chi-square test, $\mathrm{p}=0.254$. When considering two ranges only: chisquare test, $\mathrm{p}=0.643$ ). 


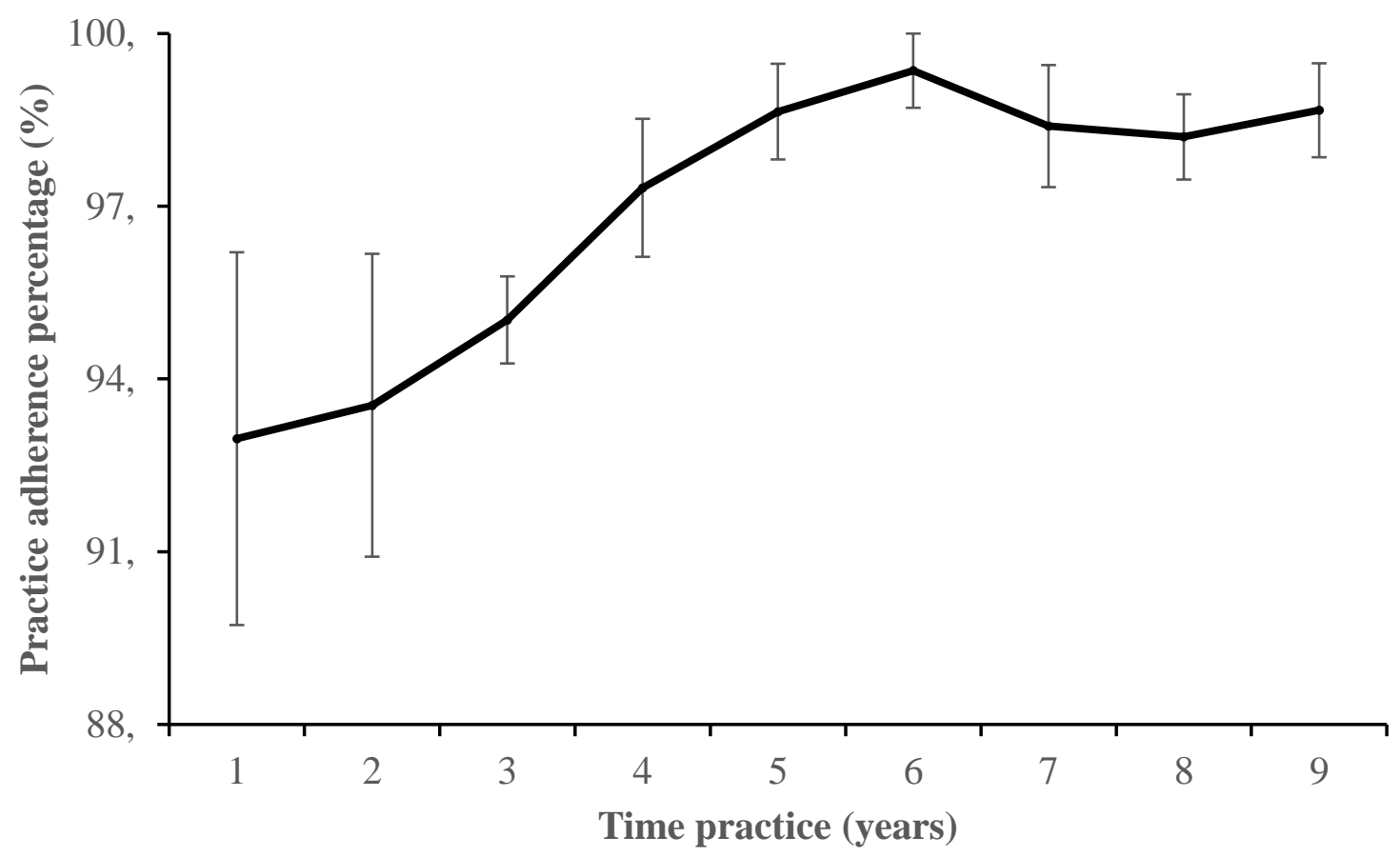

Figure 3. Average percentage of adherence to professional practice among FAODO-UFMS' graduates from 1.1971 to 9.2015 , per five-years period

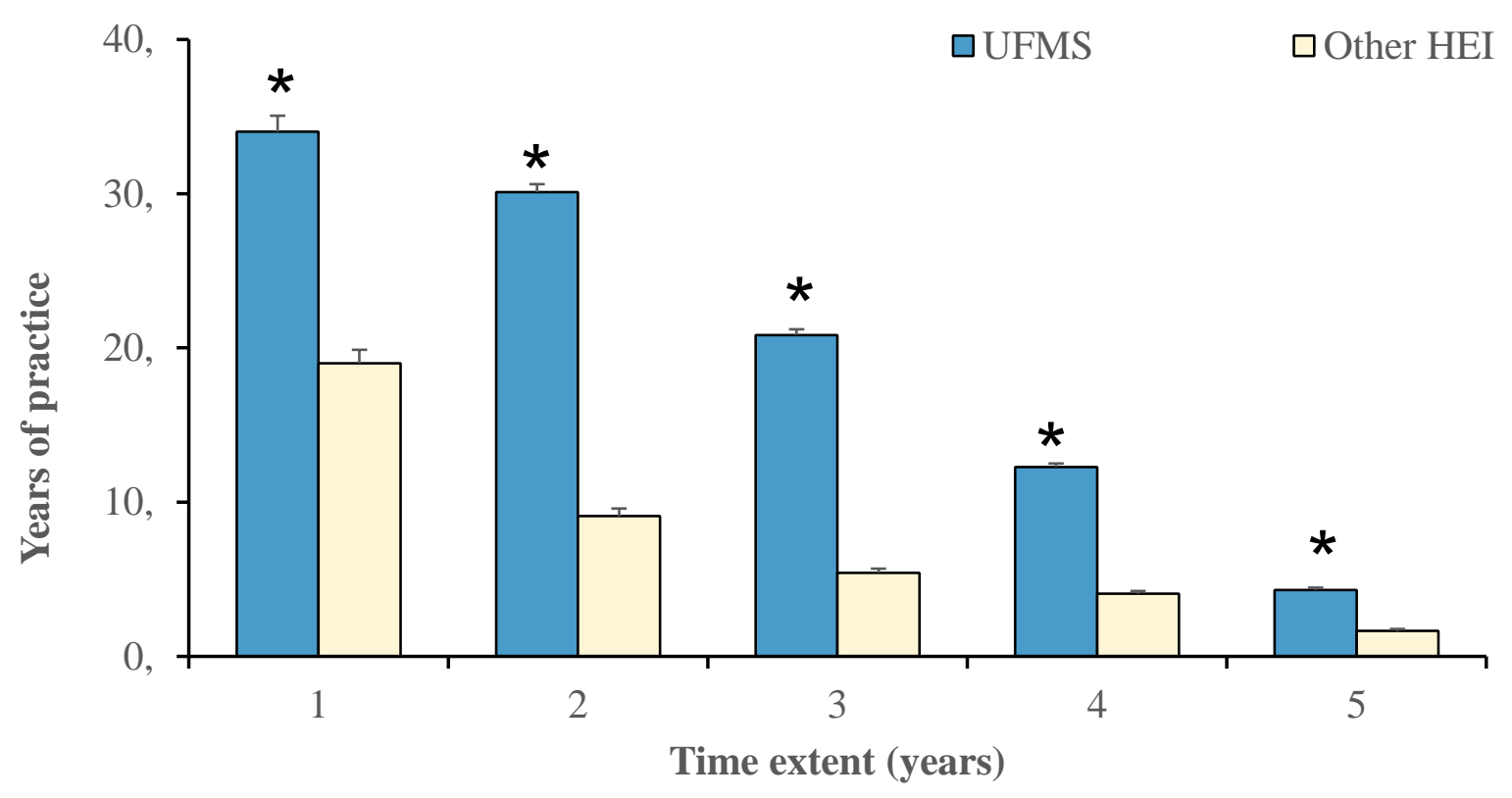

Figure 4. Years of practice among graduates at FAODO-UFMS and those from other HEI, in decades, from 1. 1971 up to 5. 2020. * Significant difference concerning graduates from other HEI (Student's $t$-test, $\mathrm{p}<0.001)$ 


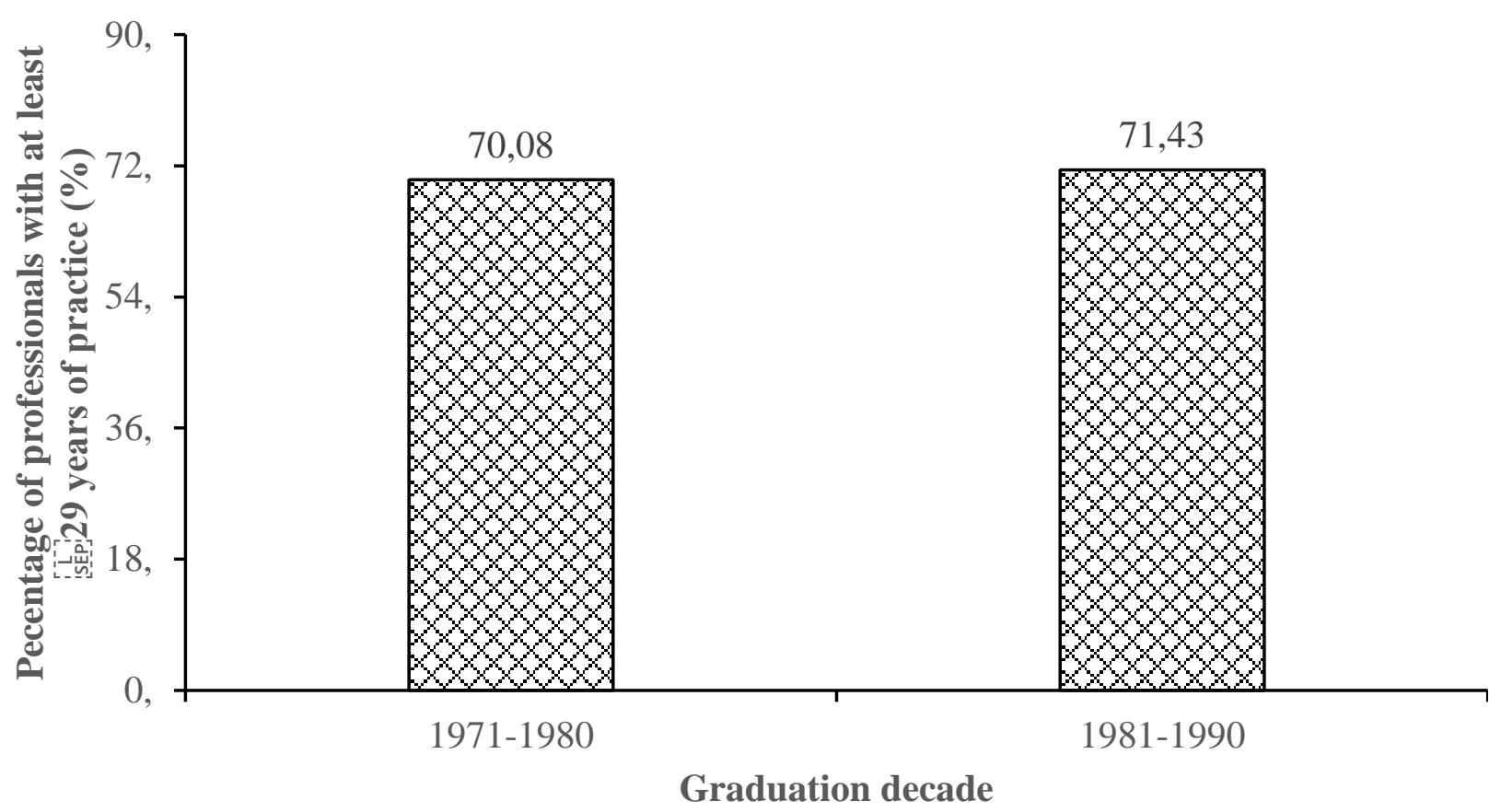

Figure 5. Percentage of professionals who graduated at FAODO-UFMS and worked for at least 29 years in the decades between 1. 1971-1980 to 2. 1981-1990

\section{DISCUSSION}

This study shows that there was a significant increase in dropout rates from FAODO-UFMS when using the USS selection method. Regarding professional practice, it was identified that the adherence of FAODO-UFMS graduates to Dentistry's professional practice is high, and this index decreased in the period between 1998 and 2008, when it started to increase once more. It was shown that the time of professional practice for Dentistry has decreased in the state in recent decades, especially among those who graduated from other HEIs, rather than FAODO-UFMS.

Dropping out may include various concepts, including taking a leave of absence, abandoning the university and abandoning the educational system ${ }^{1,2,3,10,13}$. The analysis of dropout rates using the apparent cohort method ${ }^{28}$, which compares the number of graduates with the number of students admitted to the HEI, may reveal inconsistent results, making it possible to observe course completion rates above $100 \%$, when not all those who graduated from a given course attended school regularly, leading to a higher number of graduates than admitted students in certain classes. To minimize this bias, in this study, the dropout rate was calculated using the identification of students who graduated, even if it took them longer than the regularly envisaged.

There is a diversity of school dropout factors, which also vary from one course to another, between institutions, from one region of the country to another, between countries and considering their historical context, because it has long been investigated ${ }^{1,2,5,6,10,11,25,28-33}$. Among the factors related to the student, we can 
differentiate the pre-university ones, such as parents' schooling ${ }^{4}$, advice and support from friends and family regarding the career choice, previous exposure to stimulating environments and situations, personal plans, gender, age, motivation, socio-demographic conditions, financial status ${ }^{3,31}$, previous qualifications ${ }^{31,34}$, early family formation ${ }^{34}$; from those that are circumstantial and individual, such as grades, commitment and feelings of personal adequacy ${ }^{3}$. Among the factors related to the institution, the structure, such as laboratories, services, classrooms, equipment and library, the existence of financial support, such as student's scholarships and loans ${ }^{3}$ and the quality of the faculty $^{29}$ should be highlighted. The student's educational background and that of the teachers' are reflected in the learning environment of the student group ${ }^{30}$. The number of classes influences the teachers' performance ${ }^{30}$, which reflects on the student's stimulus. The social environment of the university influences the student ${ }^{31}$. However, the system of admission to higher education has received less attention and divergent views regarding the impact on dropout rates; when previously presented results did not identify this factor as related to dropout rates ${ }^{24}$, other studies pointed them out as being inextricably related to them ${ }^{13,35}$.

The statistical significance of dropout results found in this study during the period when the USS system was adopted, compared to the period when the Vestibular was used, demonstrates the strong correlation of dropout with the admission system for FAODO-UFMS, as previously observed in other studies ${ }^{11,13,36}$. The implementation of USS coincided with the increase in the number of students at FAODOUFMS class, two policies that did not show favorable results in terms of adherence to the course when considering the results of this study. The USS is a system that allows students from all over the country to apply to any course for which the score obtained in the NHSE is deemed suficient. The student's sense of inadequacy for the chosen course and the distance between the chosen HEI and the student's place of origin may result in emotional and financial impact that are already related to dropout ${ }^{3,6,25}$.

It was also observed that although the dropout rate among quota holders and students filling vacant positions was greater than that of students admitted through the nationwide competition (Vestibular), this was not statistically significant. However, it has already been considered that, although quota holders value the opportunity, the institution and the course, these students have difficulties in making progress in the academic universe ${ }^{11}$.

Dropout "itself" is considered to be negative for the above mentioned reasons. However, Vries ${ }^{32}$, who analyzes Engineering schools, which show high dropout rates, considered that this issue should be further studied. Individuals who abandon one course may enter another or the labor market, eventually ending up having more professional success than those who completed the course. Nevertheless, dropout has been occurring in courses where, traditionally, this rate was $l^{10 w^{7,9}}$; it has become a worldwide and growing phenomenon, which should be analyzed, aiming to have information to support the training that generates satisfaction for future professionals, meeting social and labor market demands. It is fundamental to approximate these sectors so that concrete objectives for higher education can be established, based on consolidated data.

Obtaining the secondary data related to graduates' professional practice from the DRCMS has shown to be a challenge. Some DRC-MS registration data were compromised due to damages apparently caused by humidity. Some graduates who registered with the DRC-MS as 
well as in other states did not leave this information in their files. In other cases, some inconsistencies were identified regarding the data recorded in the files: duplicate, or even triplicate records, as a result of the reactivation of inactive registrations. Some graduates were not listed as registered, but were identified as active in search engines, which was finally confirmed by the FCD. Some professionals are seen as active in search engines but have no registration with the DRC-MS or are not identified by the FCD. Some Regional Councils have not returned requests for information regarding the activity of professionals they have registered, such as the DRC of São Paulo and the one of Rio de Janeiro.

The implementation of the Regional and Federal Councils of Dentistry was defined by Law N. 4.324, of April 14, $1964^{37}$, but the Dentistry Regional Council of Mato Grosso (DRC-MT) was created in 1971, following the regulation of Decree N. 68.704, of June 3, $1971^{38}$ and that of MS was created on January 1, 1978, after the division of the state into two. Those who graduated from FAODO-UFMS between 1968 and 1971 were registered in the DRC-MT in that last year and, after the division into two states, the registrations of those who were practicing in the new state of MS were kept and those who graduated after that date were welcomed.

In relation to the practice of Dentistry, the data obtained reveal a decrease in the average time of practice in the most recent period, which is even more significant among the graduates from other HEIs who work in the state of MS. The correlation between the number of professionals and time of practice did not show any statistical difference, but there is an increase in the percentage of professionals working for a short period over the decades. The reasons that determine this behavior encourage future studies.

A limitation of this study is the number of graduates in recent decades, which may have influenced the results regarding the correlation between the number of graduates and time of practice, compared to the previous decades. This is a temporal issue that cannot be controlled by the study design. This limitation may be overcome in future studies, when the number of graduates will allow further investigations. Moreover, for the next proposals related to study object, mixed methodological designs (triangulation of methods) are suggested. This is necessary to expand the understanding of individual and contextual issues inherent to admission systems and affirmative actions, which include procedural aspects and not only results such as student performance. These characteristics practically demand the implementation of qualitative methodological strategies, which may clarify subjective aspects of quantitative studies' objective contributions. When considering the potentialities of different methods, answers that are more robust are visualized on the impact of relevant questions that greatly affect the lives of students and teachers and the university context.

The analysis of the behavior of the graduates from FAODO-UFMS in the labor market, presented in this study, is unprecedented in the literature and precious for those who are interested in applying to the course. In this context, one might consider what Vries pondered in $2011^{32}$, when he pointed out that higher education dropout may not be an unfavorable event. The students may turn out to be more successful professionally or more satisfied with the practice of another professional activity before many years of their life have been spent until they reassess their initial choice or professional frustration leads them to reflect upon that. Moreover, there have been changes in dental practice paradigms, such as the model of care in private practice being replaced by care in public health promotion environments ${ }^{39}$. In these 
locals, theoretical and methodological bases are created by the best scientific evidence, together with the possibility of generating a greater social impact, since its goal is the health-disease process in human collectivities. These issues encourage new investigations that bring subsidies to define new directions for education in Dentistry.

\section{CONCLUSIONS}

The use of USS as an admission system showed a strong correlation with dropout rates at the FAODO-UFMS during the analyzed period. Both USS and increase in vacancy at FAODOUFMS did not show favorable results when related to adherence to the course. The average time of professional practice in Dentistry has decreased in recent decades, especially for the graduates from other HEIs, other than FAODOUFMS.

\section{ACKNOWLEDGEMENTS}

This study was supported by the UFMS.

\section{RESUMO}

Taxas de evasão dos estudantes de Odontologia e adesão à prática profissional entre os formados por uma instituição pública Este estudo apresenta uma análise quantitativa dos dados relacionados à taxa de evasão na Faculdade de Odontologia da Universidade Federal do Sul de Mato Grosso (FAODO-UFMS) e à atividade profissional de seus licenciados, abrangendo o período entre a sua implantação, em 1964, até ao ano 2015. Os dados obtidos foram associados ao sistema de admissão existente durante esse período. Foi investigada a adesão dos diplomados à prática profissional e a duração da prática profissional destes licenciados e dos diplomados em outras Instituições de Ensino Superior (IES), no estado do Mato Grosso do Sul (MS). Foi adotado um nível de significância de $5 \%$. O Sistema de Seleção Unificado (SISU) tem uma forte correlação com a taxa de evasão na
FAODO-UFMS. Não houve diferença estatística na comparação entre estudantes que foram admitidos por concurso nacional (Vestibular), Cotas, ou para utilização de vagas ociosas. O tempo médio de prática da Odontologia diminuiu no MS nas últimas décadas, sendo a dos licenciados de outras IES estatisticamente inferior $(\mathrm{p}<0,001)$ àquela dos que se graduaram na FAODO-UFMS. Dos formados nos anos de 1971 à 1990, a percentagem daqueles que estiveram/estão na prática há mais de 30 anos atingiu 71,43\%. A taxa de evasão, na FAODO-UFMS aumentou com a utilização do SISU como sistema de admissão. Tanto o SISU como o aumento de vagas na FAODOUFMS não mostraram resultados favoráveis com relação à aderência ao curso. $\mathrm{O}$ tempo médio de prática da Odontologia no MS tem diminuído, especialmente para aqueles que não se graduaram na FAODO-UFMS.

Descritores: Evasão. Ensino Superior. Prática Profissional.

\section{REFERENCES}

1. Gomes MJ, Mariano J, Damasceno AM, Almeida TJS, Carvalho RB. Evasão Acadêmica no Ensino Superior: Estudo na Área da Saúde. Rev Bras Pesqui Saúde. 2010 12(1):6-13.

2. Baggi CAS, Lopes DA. Evasão e avaliação institucional no ensino superior: uma discussão bibliográfica. Avaliação. 2011 16(2):355-4.

3. Lobo R. A Evasão No Ensino Superior Brasileiro - Novos Dados. Estadão. 2017. [Cited: 08 Jan. 2018]. Available from: http://educacao.estadao.com.br/blogs/robert o-lobo/497-2/.

4.Can E, Aktas FO, Aparcioglu IT. The Reasons of School Dropout in Higher Education: Babaeski Vocational College Case. Univ J Educ Res. 2017 5(12A): 84-8.

5.Kim D, Kim S. Sustainable Education: Analyzing the Determinants of University Student Dropout by Nonlinear Panel Data 
Models. Sustainability. 201810:954-82.

6.Bound J, Lovenheim MF, Turner S. Why have college completion rates declined? An analysis of changing student preparation and collegiate resources. Am Econ J Appl Econ. 2010 2:129-57.

7.Larsen MR, Sommersel HB, Larsen MS. Evidence on Dropout Phenomena at Universities. Danish Clearinghouse for Educational Research: Copenhagen, NV, USA, 2013. [Cited: 08 Jan. 2018]. Available from: https://edu.au.dk/fileadmin/edu/ Udgivelser/Clearinghouse/Review/Evidenc e_on_dropout_from_universities_brief_vers ion.pdf.

8.INEP - Instituto Nacional de Estudos e Pesquisas Educacionais Anísio Teixeira. Sinopse estatística da Educação Superior 2015. Brasília 2015. [Cited: 09 June 2018]. Available from: http://inep.gov.br/sinopsesestatisticas-da-educacao-superior.

9.Portal do Brasil. MEC defende reformas para reduzir evasão em faculdades. Governo do Brasil. 2016. [Cited: 09 June 2018]. Available from: http://www.brasil.gov.br/ educacao/2016/10/mec-defende-reformaspara-reduzir-evasao-em-faculdades.

10. INEP - Instituto Nacional de Estudos e Pesquisas Educacionais Anísio Teixeira. Sinopse estatística da Educação Superior 2018 Brasília: INEP, 2019. [Cited: 09 June 2018]. Available from: http://inep.gov.br/ sinopses-estatisticas-da-educacao-superior.

11. Queiroz FCBP, Samohyl RW, Queiroz JV, Lima NC, Souza GHS. Multivariate analysis for the choice and evasion of the student in a higher educational institution from southern of Santa Catarina, in Brazil. Tojde. 2014 15(4):281-302.

12. Mendes Junior AAF. Uma análise da progressão dos alunos cotistas sob a primeira ação afirmativa brasileira no ensino superior: o caso da Universidade do Estado do Ensaio: Aval Pol Publ Educ. 2014 22(82):31-56.

13. Ferrão ME, Almeida LS. Multilevel modeling of persistence in higher education. Aval Pol Públ Educ. 2018 26(100):664-83. [Cited: 08 Jan. 2018]. Available from: http://www.scielo.br/scielo.php?script=sci arttext\&pid=S0104-40362018000300664\& lang=pt.

14. Souza JM, Santos BST, Ramona FC. Retenção e evasão no Ensino Superior público: estudo de caso em um curso noturno de Odontologia. Educ Rev. 2017 33:1-26.

15. Brahm T, Jenert T, Wagner D. The crucial first year: a longitudinal study of students' motivational development at a Swiss Business School. J High Educ. 2017 73:45978.

16. Sistema de Acceso Educación Superior. [Cited: 05 May 2018]. Available from: https://educacionsuperior.mineduc.cl/sobreel-nuevo-sistema-de-acceso/educacionuniversitaria/.

17. Le baccaulaureat general. [Cited: 05 May 2018]. Available from: https://www. education.gouv.fr/le-baccalaureat-general10457.

18. Korean Institute for Curriculum and Evaluation. [Cited: 05 May 2018]. Available from: http://www.suneung.re.kr/main.do?s =suneung.

19. National Center for University Entrance Examinations. [Cited: 05 May 2018]. Available from: https://www.dnc.ac.jp/.

20. Portaria MEC $\mathrm{N}^{\circ} 438$, DE 28 DE MAIO DE 1998. [Cited: 08 Jan. 2018]. Institui o Exame Nacional do Ensino Médio - ENEM. Available from: www.crmariocovas. sp.gov.br/pdf/diretrizes_p0178-0181_c.pdf .

21. Ministério da Educação (Brasil). Portaria $\mathrm{n}^{\circ} 02$, de 26 de Janeiro de 2010. Institui e 
regulamenta o Sistema de Seleção Unificada, sistema informatizado gerenciado pelo Ministério da Educação, para seleção de candidatos a vagas em cursos de graduação disponibilizadas pelas instituições públicas de educação superior dele participantes. Diário Oficial União. 27 jan 2010; Seção 1. [Cited: 08 Jan. 2018]. Available from: http://portal.mec.gov.br/ index.php?option $=$ com docman\&view $=$ do wnload\&alias=2704-sisuportarianormativa2 \&Itemid=30192.

22. Lei n ${ }^{\circ} 9394$, de 20 de dezembro de 1996. Estabelece as diretrizes e bases da educação nacional. [Cited: 08 Jan. 2018]. Available from: $\quad$ http://www.planalto.gov.br/ccivil 03/leis/19394.htm.

23. Lei $n^{\circ} 12.711$ de 29 de agosto de 2012. Dispõe sobre o ingresso nas universidades federais e nas instituições federais de ensino técnico de nível médio e dá outras providências. [Cited: 08 Jan. 2018]. Available from: http://portal.mec. gov.br/cotas/docs/lei_12711_29_08_2012.p df.

24. Gilioli RSP. Evasão em Instituições Federais de ensino superior no Brasil: Expansão de rede, SISU e desafios. Câmara dos deputados. 2016. [Cited: 08 Jan. 2018]. Available from: http://www2.camara. leg.br/a-camara/documentos-e-pesquisa/ estudos-e-notas-tecnicas/areas-da-conle/ tema11/2016_7371_evasao-em-instituicoesde-ensino-superior renato-gilioli.

25. Destrobecq A, Desrefani C, Spoton A. Abandonment of nursing courses: a survey regarding the motivations, which lead the students to the abandonment of the nursing degree course. Prof Inferm. 2008 61(2):806.

26. Costa SM, Durães SJ, Abreu MHNM, Bonan PRF, Vasconcelos M. Motivos de escolha da
Odontologia: vocação, opção ou necessidade? Arq Odontol. 2010 46(1): 2837.

27. Aguiar CM, Pessoa MA, Câmara AC, Perrier RA, de Figueiredo JA. Factors involved in the choice of dentistry as an occupation by Pernambuco dental students in Brazil. J Dent Educ. 2009 73(12):1401-7.

28. Martínez F. "Estudio de la eficiencia en cohortes aparentes", en anuies (2001), Deserción, rezago y eficiencia terminal en las IES. Propuesta metodológica para su estudio, México, anuies, 2001. [Cited: 13 Oct. 2018]. Available from: http://www.coepesguanajuato.mx/press/Doc umentos/5parte/5.4/estudio.

29. Simpson C, Baker K, Mellinger G. Conventional failures and unconventional dropout: Comparing different types of university withdrawals. Sociol Educ. 1980 53:203-214.

30. Astin AW. Student involvement: A developmental theory for higher education. J. Coll. Stud. Dev. 1999 40:518-529.

31. Titus MA. Understanding the influence of the financial context of institutions on student persistence at four-year colleges and universities. J High Educ. 2006 77:353-75.

32. Vries W, Arenas PA, Muñoz JFR, Saldaña IS. Dropout or disappointed? Different reasons for dropping out of higher education. Rev Educ Sup. 2011 4:29-50.

33. Sharpe AS. Un analises histórico del abordaje sobre el abandono universitário en Argentina. Sahe. 2016 17(2):3-31.

34. Ashour S. Analysis of the attrition phenomenon through the lens of university dropout in the United Arab Emirates. J Appl Res High Educ. 2019. [Cited: 14 Sept. 2018]. Available from: https://www. emerald.com/insight/content/doi/10.1108/J ARHE-05-2019-0110/full/html?skip 
Tracking=true.

35. Zając TZZ, Komendant-Brodowska A. Premeditated, dismissed and disenchanted higher education dropout in Poland. Tert Educ Manag. 2019 25:1-16.

36. Barbosa PJG, Portilho LA, Miranda GJ, Tavares M. A Adoção do SISU e a Evasão na Universidade Federal de Uberlândia. Rev Ibero Am Estud em Educ. 2017 12:722-38.

37. Lei n 4.324 , de 14 de abril de 1964. Institui o Conselho Federal e os Conselhos Regionais de Odontologia, e dá outras providências. [Cited: 10 Aug. 2018]. Available from: http://www.planalto.gov. br/ccivil_03/leis/1950-1969/L4324.htm.
38. Decreto n68.704, de 03 de junho de 1971. Ementa. Regulamenta a Lei ${ }^{\circ} 4.324$, de 14 de abril de 1964. [Cited: 10 Aug. 2018]. Available from: http://www.planalto.gov.br/ ccivil_03/decreto/1970-1979/D68704.htm.

39. Ferreira NP, Ferreira AP, Freire MCM. Mercado de trabalho na Odontologia: contextualização e perspectivas. Rev Odontol UNESP. 2013 42(4):304-9.

\section{Correspondência para:}

Jussara Peixoto Ennes

e-mail: jussarapeixotoennes@gmail.com

Rua Aluízio de Azevedo, 1330/302B

79004-050 Campo Grande/MS Brazil 